\title{
MANIPULASI CAHAYA UNTUK MENURUNKAN KELIMPAHAN NEMATODA PARASIT TUMBUHAN PADA PEMBIBITAN KOPI
}

\author{
I Gede Swibawa1, Dwisyah Putra ${ }^{2}$, F.X. Susilo ${ }^{1}$, Kurniatun Hairiah ${ }^{3}$ \& Didik Suprayogo $^{3}$
}

\begin{abstract}
Light manipulation to reduce the plant parasitic nematodes abundance on coffee nursery. Plant parasitic nematode problem on monoculture coffee can be caused not only by the suitable hosts but also by the environmental changes, such as soil water content and soil temperature. A semi-field experiment was conducted in Sumberjaya, West Lampung on MaySeptember 2007 with the aim to study the effect of shading levels and fertilizer levels of coffee nursery on plant parasitic nematodes abundance. The results showed that the shading level treatment on coffee nursery significantly affected the abundance of plant parasitic nematodes but did not affect the free-living nematode abundance. The relationship between the plant parasitic nematode abundance with the shading level is polynomial with the highest nematode abundance (500 individual/ $300 \mathrm{ml}$ of soil) was under $40 \%$ shading level. The increase in shading level indirectly affected the increase in plant parasitic nematode abundance through the increas in of soil water content. Inorganic N, P and K fertilizer at the recommended level for coffee nursery increased the abundance of plant parasitic nematodes from 216 to 282 individual $/ 300 \mathrm{ml}$ of soil. The interaction between the shading level and fertilizer did not significantly affect the plant parasitic nematode abundance.
\end{abstract}

Key words: shading level, nematodes, coffee nursery

\section{PENDAHULUAN}

Masalah hama dan penyakit tanaman termasuk nematoda kerap muncul pada pertanian dengan pola tanam monokultur (Altieri \& Nicholls, 2004). Hasil survei tingkat kawasan di Sumberjaya, Lampung Barat menunjukkan bahwa hutan yang diubah menjadi pertanaman kopi monokultur menyebabkan peningkatan kelimpahan nematoda parasit tumbuhan sekitar $60 \%$ (Swibawa et al., 2006). Sementara itu, di daerah tersebut pola tanam kopi monokultur lebih dominan daripada pola campuran atau agroforestri (Afandi, 2004). Peningkatan kelimpahan nematoda parasit tumbuhan tersebut perlu mendapat perhatian karena dapat memunculkan masalah pada masa yang akan datang.

Perubahan lingkungan fisik tanah dalam suatu sistem penggunaan lahan juga dapat memacu munculnya masalah hama dan penyakit tanaman. Pada kopi sistem monokultur, perubahan iklim mikro tanah seperti suhu dan kelembaban tanah merupakan salah satu pemacu munculnya masalah hama dan penyakit termasuk nematoda parasit tumbuhan (Schroth et al., 2000).
Perubahan iklim mikro ini terjadi pada lahan terbuka seperti ketika tanaman masih berumur muda, karena tingkat tutupan kanopi pohonnya rendah. Menurut Aini et al. (2006) tutupan kanopi pada pertanaman kopi sistem monokultur sekitar $45 \%$ lebih rendah daripada di hutan alami. Akibatnya, suhu tanah di kopi monokultur lebih tinggi $\left(20,6^{\circ} \mathrm{C}\right)$ dibandingkan suhu tanah di hutan $\left(20,3^{\circ} \mathrm{C}\right)$.

Air di dalam tanah merupakan faktor lingkungan penting bagi nematoda dalam tanah. Porositas tanah dan keberadaan lapisan tipis (film) air pada partikel tanah dapat menjadi faktor kritis bagi aktivitas nematoda parasit tumbuhan (Lee \& Atkinson, 1997; Norton, 1978). Sementara itu, tanaman yang tumbuh pada tanah berkadar air rendah dan tidak subur akan lemah dan rentan terhadap serangan nematoda parasit tumbuhan. Biota antagonis pengendali alami juga tidak akan bekerja efektif pada tanah berkadar air rendah. Hal ini akan lebih memacu timbulnya masalah nematoda pada suatu lahan pertanian. Menurut Hairiah et al. (2000), kadar air tanah dapat dipertahankan tetap tinggi dengan penerapan sistem agroforestri karena sistem ini dapat

\footnotetext{
1 Jurusan Proteksi Tanaman, Fakultas Pertanian, Universitas Lampung,

Jl. Prof. Sumantri Brodjonegoro No. 1 Bandar Lampung 35145. E-mail: igswibawa@unila.ac.id dan igswibawa@yahoo.com

${ }^{2}$ Alumnus Jurusan Proteksi Tanaman, Fakultas Pertanian, Universitas Lampung

${ }^{3}$ Jurusan Ilmu Tanah, Fakultas Pertanian, Universitas Brawijaya,

Jl. Veteran Malang 65145
} 
meningkatkan tutupan kanopi dan masukan serasah. Melalui pengaturan pemangkasan pohon penaung, cahaya yang sampai ke tanah dapat dimanipulasi. Sementara itu pada pembibitan kopi manipulasi cahaya pada umumnya menggunakan naungan buatan. Menurut Najiyati \& Danarti (2007), naungan buatan pada pembibitan kopi juga berperan untuk mempertahankan kadar air tanah tetap tinggi karena berkurangnya evaporasi dan evapotranspirasi.

Desaeger et al. (2004) menjelaskan bahwa masalah nematoda parasit tumbuhan lebih banyak terjadi pada tanaman yang tumbuh pada tanah-tanah tidak subur atau tanaman yang kahat hara dan keracunan aluminium. Pada umumnya upaya untuk meningkatkan kesehatan tanaman pada tanah yang tidak subur adalah dengan penambahan pupuk anorganik secara berimbang. Dengan memberi nutrisi berimbang ketahanan tanaman terhadap gangguan hama dan penyakit, termasuk nematoda dapat ditingkatkan (Agrios, 1997). Pengaturan tutupan kanopi dan penambahan pupuk anorganik diperkirakan dapat mengurangi resiko munculnya masalah nematoda pada pembibitan kopi. Namun, hal ini masih perlu diteliti lebih lanjut. Tujuan penelitian ini adalah untuk mempelajari pengaruh tingkat kerapatan naungan serta pemupukan (N, P dan $\mathrm{K}$ ) terhadap kelimpahan nematoda parasit tumbuhan pada pembibitan kopi.

\section{METODE PENELITIAN}

Percobaan semi-lapangan dilakukan di Sumberjaya, Lampung Barat yang merupakan sentra perkebunan kopi rakyat. Sebagian besar kebun kopi rakyat di daerah ini merupakan alih fungsi hutan. Percobaan berlangsung mulai bulan Mei sampai September 2007.

Pelaksanaan Penelitian. Perlakuan dalam percobaan ini disusun dalam Rancangan Acak Kelompok (RAK) faktorial 4 x 2 dengan 3 ulangan. Faktor pertama adalah tingkat kerapatan naungan yang terdiri atas 4 taraf yaitu tanpa naungan (0\%), 50\%, 70\% dan 90\%. Faktor kedua adalah pemupukan $\mathrm{N}, \mathrm{P}$ dan $\mathrm{K}$ yang terdiri atas dua taraf yaitu (1) tanpa dipupuk sebagai kontrol dan (2) dipupuk dengan dosis anjuran yaitu $\mathrm{N}, \mathrm{P}$ dan $\mathrm{K}$, berturut-turut 90, 60 dan $40 \mathrm{~kg} \mathrm{ha}^{-1}$. Penentuan letak kelompok plot di lapangan berdasarkan arah datangnya sinar matahari, yaitu tegak lurus arah baris plot.

Lahan percobaan yang digunakan merupakan bekas semak/alang-alang yang diolah dua kali dengan cangkul sampai kedalaman $20 \mathrm{~cm}$. Sifat fisika-kimia tanah lahan percobaan adalah sebagai berikut: $\mathrm{pH} \mathrm{H}_{2} \mathrm{O}$ $=4,5 ; \mathrm{pH} \mathrm{KCl}=3,78 ; \mathrm{C}(\%)=2,20 ; \mathrm{N}(\%)=0,16 ; \mathrm{P}$ $\left(\mathrm{mg} \mathrm{kg}^{-1}\right)=0,28 ; \mathrm{K}\left(\mathrm{cmol} \mathrm{l}^{-1}\right)=0,15$; pasir $(\%)=27,91$; debu $(\%)=23,36$; liat $(\%)=48,55$; dan $\mathrm{BD}\left(\mathrm{g} \mathrm{cm}^{-3}\right)=$ 0,99 . Bibit kopi yang digunakan merupakan hasil persemaian biji kopi arabika (Coffea arabica) varietas Kartika-1 di rumah kaca Fakultas Pertanian Universitas Lampung pada media pasir steril. Kopi arabika dipilih sebagai bahan percobaan karena rentan terhadap serangan nematoda (Hulupi et al., 2006). Biji kopi diperoleh dari kebun petani di Sumberjaya, Lampung Barat. Bahan naungan adalah jaring plastik warna hitam (paranet) yang tersedia di pasaran dengan tingkat kerapatan naungan $70 \%$. Untuk mendapatkan tingkat kerapatan naungan 50\%, sebagian serat jaring dibuang, sedangkan untuk mencapai tingkat kerapatan naungan $90 \%$, jaring dipasang berlapis dua. Peneraan tingkat kerapatan naungan dilakukan menggunakan lux meter. Pupuk yang digunakan adalah Urea, TSP, dan $\mathrm{KCl}$, masing-masing sebagai sumber $\mathrm{N}, \mathrm{P}$ dan $\mathrm{K}$, yang diperoleh dari kios sarana produksi pertanian di Sumberjaya, Lampung Barat.

Petak-petak berukuran $1 \mathrm{~m} \times 1 \mathrm{~m}$ dibuat pada plot percobaan berukuran $30 \mathrm{~m}$ x $15 \mathrm{~m}$, dengan jarak antar petak percobaan $1 \mathrm{~m}$. Petak percobaan ditanami bibit kopi berdaun 4 (24 minggu setelah semai) secara monokultur dengan jarak tanam $20 \mathrm{~cm}$ x $20 \mathrm{~cm}$.

Aplikasi pupuk N, P dan $\mathrm{K}$ dengan dosis sesuai perlakuan dilakukan 7 hari setelah tanam dengan cara menaburkan secara merata pada alur di antara baris bibit kopi. Dosis anjuran disesuaikan dengan kandungan unsur N, P dan K dalam tanah. Perawatan tanaman meliputi penyiraman bila tidak hujan dan penyiangan gulma. Gangguan hama perusak daun dikendalikan secara mekanik.

Pengamatan kelimpahan nematoda dilakukan 4 kali yaitu pada awal percobaan dan pada saat tanaman berumur 1, 2 dan 3 bulan setelah tanam. Sekitar $500 \mathrm{~g}$ contoh tanah diambil menggunakan cetok kebun dari 5 sub-titik contoh pada kedalaman 0-20 cm menurut kedua arah diagonal petak. Ekstraksi nematoda dari tanah dilakukan dengan metode penyaringan dan sentrifugasi menggunakan larutan gula serta penghitungan nematoda dilakukan menurut metode standar CSM-BGBD (Gafur \& Swibawa, 2004). Nematoda diidentifikasi dan dipilah menjadi 2 kelompok makan yaitu nematoda parasit tumbuhan dan nematoda hidup bebas (nir-parasit tumbuhan).

Pertumbuhan bibit kopi ditentukan dengan menetapkan biomasa tanaman (berat kering akar dan tajuk) serta kerusakan berupa bercak nekrotik pada akar 
tanaman umur 3 bulan setelah tanam. Dalam setiap petak, 5 contoh tanaman dipilih secara sistematik menurut arah kedua diagonal petak dan tanaman didongkel dengan cetok kebun secara hati-hati untuk mengurangi jumlah akar yang putus. Akar dan tajuk tanaman dioven pada suhu $80^{\circ} \mathrm{C}$ selama 48 jam dan ditetapkan berat keringnya. Nekrotik akar diamati dari 20 potongan akar contoh berukuran $1 \mathrm{~cm}$ yang diambil secara acak dari setiap tanaman dan dinyatakan dalam persen.

Suhu tanah pada kedalaman $20 \mathrm{~cm}$ dan suhu udara di bawah naungan diukur menggunakan termometer air raksa berbentuk batang. Pada setiap bulan, suhu tanah dan suhu udara diamati selama 4 hari berturut-turut. Suhu harian dihitung dari rata-rata tiga kali pengukuran yaitu pagi (pukul 06.00), siang (pukul 14.00), dan sore (pukul 17.00). Pengamatan kadar air tanah menggunakan metode gravimetri dilakukan pada tanaman umur 3 bulan setelah tanam.

Analisis Data. Data kelimpahan nematoda parasit dan nematoda hidup bebas, suhu dan kadar air tanah, serta biomassa tanaman dianalisis ragam menggunakan program komputer SAS for Windows Versi 12.6 (SAS Institute, 1990). Analisis regresi polinomial, regresi linier dan korelasi linier diterapkan untuk menggambarkan hubungan tingkat naungan dengan kelimpahan nematoda parasit tumbuhan; hubungan tingkat naungan dengan biomassa tanaman; menggambarkan hubungan tingkat naungan dengan kondisi iklim mikro dan hubungan peubah kelimpahan nematoda parasit tumbuhan dan kerusakan akar dengan biomassa tanaman. Semua analisis statistik menggunakan taraf nyata $1 \%$ atau $5 \%$.

\section{HASIL DAN PEMBAHASAN}

Pengaruh Tingkat Kerapatan Naungan dan Pemupukan (N, P dan K) terhadap Kelimpahan Nematoda. Hasil analisis ragam menunjukkan bahwa perlakuan tingkat kerapatan naungan, pemupukan, dan interaksi keduanya tidak berpengaruh nyata $(P>0,05)$ terhadap kelimpahan nematoda parasit tumbuhan pada bibit kopi pada awal percobaan dan saat tanaman berumur 1 bulan. Namun, pada bibit umur 2 dan 3 bulan setelah tanam, perlakuan tingkat kerapatan naungan berpengaruh sangat nyata $(P<0,01)$ terhadap kelimpahan nematoda parasit tumbuhan tetapi tidak berpengaruh nyata $(P>0,05)$ terhadap kelimpahan nematoda hidup bebas, sedangkan perlakuan pemupukan hanya berpengaruh nyata $(P<0,05)$ terhadap kelimpahan nematoda parasit tumbuhan pada bibit kopi umur 3 bulan setelah tanam. Interaksi kedua perlakuan tersebut tidak berpengaruh nyata $(P>0,05)$ terhadap kelimpahan nematoda parasit tumbuhan maupun nematoda nirparasit tumbuhan (Tabel 1).

Pada saat bibit kopi berumur 2 dan 3 bulan, hubungan kelimpahan nematoda parasit tumbuhan dengan tingkat kerapatan naungan mengikuti model polinomial (Gambar 1). Peningkatan tingkat kerapatan naungan pada pembibitan pada kisaran $0-40 \%$ menyebabkan peningkatan kelimpahan nematoda parasit tumbuhan, sedangkan pada kisaran lebih besar dari 4090\% menyebabkan penurunan kelimpahan nematoda tersebut. Kelimpahan maksimum nematoda parasit tumbuhan terjadi pada tingkat kerapatan naungan sekitar $40 \%$ yaitu sekitar 500 dan 400 individu/300 ml tanah, berturut-turut pada bibit kopi umur 2 dan 3 bulan.

Tabel 1. Nilai $P$ (taraf nyata) analisis ragam pengaruh naungan dan pemupukan $(\mathrm{N}, \mathrm{P}$ dan $\mathrm{K}$ ) terhadap kelimpahan nematoda pada pembibitan kopi umur 2 dan 3 bulan setelah tanam

\begin{tabular}{lcccc}
\hline \multirow{2}{*}{ Perlakuan } & \multicolumn{2}{c}{ Bibit kopi } & umur 2 bulan & \multicolumn{2}{c}{ Bibit kopi } & umur 3 bulan \\
\cline { 2 - 5 } & Par Tbh & Nir-par Tbh & Par Tbh & Nir-par Tbh \\
\hline Naungan & $0,01^{* *}$ & $0,11 \mathrm{tn}$ & $0,0001^{* *}$ & $0,12 \mathrm{tn}$ \\
Pupuk & $0,16 \mathrm{tn}$ & $0,37 \mathrm{tn}$ & $0,01^{* *}$ & $0,94 \mathrm{tn}$ \\
Naungan x Pupuk & $0,65 \mathrm{tn}$ & $0,56 \mathrm{tn}$ & $1,0 \mathrm{tn}$ & $0,60 \mathrm{tn}$ \\
\hline
\end{tabular}

Keterangan: $\mathrm{Par} \mathrm{Tbh}=$ nematoda parasit tumbuhan, Nir-par $\mathrm{Tbh}=$ nematoda hidup bebas, $\mathrm{tn}=$ tidak nyata, dan $* *=$ sangat nyata. 
Secara umum, kelimpahan nematoda parasit tumbuhan pada bibit kopi umur 3 bulan lebih rendah dari pada bibit kopi umur 2 bulan setelah tanam.

Hasil percobaan menunjukkan bahwa pada tingkat kerapatan naungan yang tinggi kelimpahan nematoda parasit tumbuhan akan rendah. Hasil ini mendukung hasil survei inventarisasi pada tingkat kawasan di Sumberjaya yang mengindikasikan bahwa kelimpahan nematoda parasit tumbuhan di hutan lebih rendah daripada di lahan alang-alang/semak dan kopi monokultur (Swibawa et al., 2006). Hutan merupakan lahan dengan tutupan kanopi yang jauh lebih tinggi dengan tingkat tutupan kanopi mencapai 100\% daripada alang-alang/ semak dan kopi monokultur (Aini et al., 2006). Yeates (1996) juga melaporkan bahwa kelimpahan nematoda parasit tumbuhan yang tinggi terdapat pada lahan semak yang memiliki tutupan kanopi rendah. Dengan demikian, peningkatan tutupan kanopi melalui penanaman pohon dalam sistem agroforestri dapat berperan menurunkan kelimpahan nematoda parasit tumbuhan. Walaupun hasil percobaan ini juga mengindikasikan bahwa lahan dalam kondisi terbuka (kerapatan naungan 0\%) dapat menekan kelimpahan nematoda, hal ini tidak dapat diimplementasikan dalam sistem pertanaman kopi di lapangan karena kopi memerlukan naungan untuk dapat tumbuh dan berproduksi dengan baik.

Hasil percobaan ini juga mengindikasikan bahwa tingkat kerapatan naungan $40 \%$ optimum bagi kelimpahan nematoda parasit tumbuhan. Dengan kata lain, resiko munculnya serangan nematoda pada tanaman kopi dapat dikurangi dengan meningkatkan kerapatan naungan menjadi lebih dari $40 \%$. Menurut Schroth et al. (2000), selain menciptakan kondisi yang cocok bagi pertumbuhan kopi, naungan pada sistem agroforestri kopi juga dapat berperan dalam mengendalikan hama dan penyakit tumbuhan. Namun, dalam perannya sebagai penekan serangan hama dan patogen, naungan dipengaruhi oleh kondisi iklim, ketinggian tempat dan jenis tanah. Dalam mengendalikan hama dan penyakit, naungan akan mempengaruhi suhu dan kelembaban tanah yang memacu peningkatan aktivitas musuh alami. Selain itu, naungan juga berperan dalam mengurangi tingkat cekaman tanaman karena dedahan cahaya yang berlebih melemahkan tanaman sehingga mudah terserang hama dan patogen tanaman.

Kelimpahan nematoda parasit tumbuhan pada tanaman kontrol (tanpa pupuk) sekitar 216 dan meningkat menjadi sekitar 282 individu/ $300 \mathrm{ml}$ tanah bila dilakukan pemupukan. Hasil percobaan ini mengindikasikan bahwa pemupukan $(\mathrm{N}, \mathrm{P}$ dan $\mathrm{K})$ meningkatkan kelimpahan nematoda parasit tumbuhan. Menurut Norton (1978), pemupukan berpengaruh tidak langsung terhadap nematoda parasit tumbuhan. Dengan pemupukan, pertumbuhan akar akan lebih baik dan nematoda parasit tumbuhan memperoleh sumber makanan yang lebih sesuai sehingga kelimpahannya meningkat. Hasil penelitian yang berbeda mengenai pengaruh pemupukan terhadap nematoda parasit tumbuhan dilaporkan oleh beberapa peneliti. Misalnya,

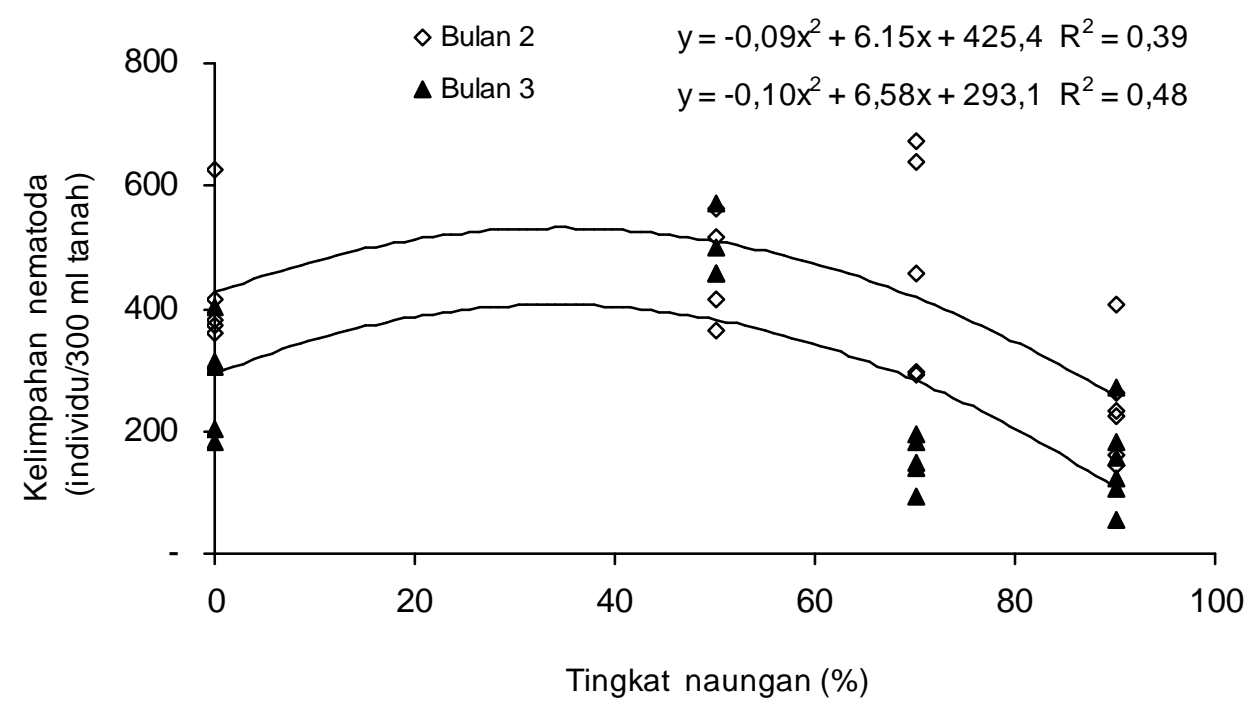

Gambar 1. Hubungan tingkat kerapatan naungan dengan kelimpahan nematoda parasit tumbuhan pada bibit kopi umur 2 bulan dan 3 bulan setelah tanam 
Smithson et al. (2001) menyebutkan bahwa pemupukan nitrogen dan potasium pada tanaman pisang tidak mempengaruhi kerusakan akar yang disebabkan oleh nematoda Radopholus similis. Melakeberhan (2007) melaporkan bahwa kelimpahan nematoda kista (Heterodera glycines) pada tanaman kedelai tidak dipengaruhi oleh aplikasi pupuk nitrogen.

\section{Pengaruh Tingkat Kerapatan Naungan terhadap} Suhu Udara, Suhu Tanah dan Kelembaban Tanah. Analisis ragam menunjukkan bahwa tingkat kerapatan naungan tidak berpengaruh nyata $(P>0,05)$ terhadap suhu udara di bawah naungan, tetapi berpengaruh sangat nyata $(P<0,01)$ terhadap suhu tanah dan kadar air tanah pada kedalaman 0-20 $\mathrm{cm}$ (Tabel 2).

Peningkatan tingkat kerapatan naungan $(\mathrm{x})$ menyebabkan penurunan suhu tanah (y) yang ditunjukkan dengan persamaan $\mathrm{y}=-0,02 \mathrm{x}+23,34$ (Gambar 2). Sebaliknya, peningkatan kerapatan naungan (x) meningkatkan kadar air tanah (y) dengan persamaan: $y=0,12 x+39,5$.

Ditemukan dua fakta dalam penelitian ini: pertama, tingkat naungan berkorelasi positif dengan kadar air tanah (Gambar 2) dan kedua, sampai tingkat $40 \%$, naungan meningkatkan kelimpahan nematoda parasit tumbuhan (Gambar 1). Kedua fakta tersebut mengindikasikan bahwa pengaruh tingkat kerapatan naungan terhadap kelimpahan nematoda parasit tumbuhan bersifat tidak langsung melalui kadar air tanah. Turunnya kelimpahan nematoda pada tingkat naungan di atas $40 \%$ disebabkan oleh sifat nematoda yang tidak menyukai kondisi kelembaban tanah yang berlebih. Walaupun nematoda merupakan biota hidrobion (Lavelle \& Spain, 2001), tetapi bila kelembaban tanah tinggi maka ia tidak dapat bertahan hidup lebih lama karena tanah dalam kondisi anaerobik (Norton, 1978). Naungan yang sangat rapat menyebabkan tanah lebih lembab dan bersifat anaerobik sehingga menekan kelimpahan nematoda parasit tumbuhan.
Pengaruh Tingkat Kerapatan Naungan dan Pemupukan (N, P dan K) terhadap Pertumbuhan Tanaman dan Kerusakan Akar. Hasil analisis ragam menunjukkan bahwa tingkat kerapatan naungan berpengaruh sangat nyata $(P<0,01)$ terhadap berat kering tanaman. Perlakuan pemupukan serta interaksinya dengan tingkat kerapatan naungan tidak berpengaruh nyata $(P>0,05)$ terhadap berat kering tanaman. Hubungan tingkat kerapatan naungan dengan berat kering tanaman mengikuti model polinomial (Gambar 3). Berat kering tanaman yang rendah terdapat pada tingkat kerapatan naungan 0 dan $90 \%$ dan tinggi pada tingkat kerapatan naungan $50 \%$. Hal ini berarti bahwa ketika tingkat naungan optimum maka pertumbuhan tanaman akan optimum pula.

\section{Hubungan antara Kelimpahan Nematoda Parasit} Tumbuhan dengan Nekrotik Akar dan Pertumbuhan Tanaman. Hasil analisis korelasi menunjukkan bahwa kelimpahan nematoda parasit tumbuhan tidak nyata $(P>0,05)$ berkorelasi dengan nekrotik akar, tetapi kelimpahan nematoda parasit tumbuhan nyata $(P<0,05)$ berkorelasi positif dengan berat kering tanaman (Tabel 3). Fakta tersebut menunjukkan bahwa walaupun kelimpahan nematoda parasit tumbuhan meningkat, namun kerusakan akar berupa nekrotik pada bibit kopi tidak meningkat. Hal ini mungkin terjadi karena nematoda parasit tumbuhan yang menyerang akar kopi tidak menimbulkan nekrotik tetapi menyebabkan gejala lain seperti akar buntung atau matinya ujung akar. Gejala kerusakan akar yang disebut terakhir ini tidak diamati dalam penelitian ini. Peningkatan biomassa tanaman diikuti oleh peningkatan kelimpahan nematoda parasit tumbuhan. Artinya, nematoda parasit tumbuhan berkembang dengan baik karena adanya akar bibit kopi, tetapi perkembangan nematoda belum sampai aras yang merusak. Serangan nematoda pada aras populasi yang belum menyebabkan

Tabel 2. Nilai $P$ (taraf nyata) analisis ragam pengaruh tingkat kerapatan naungan terhadap kondisi iklim mikro tanah pada pembibitan kopi

\begin{tabular}{cc}
\hline Kondisi iklim mikro tanah & Tingkat kerapatan naungan $(\%)$ \\
\hline Suhu Udara $\left({ }^{\circ} \mathrm{C}\right)$ & 0,4200 tn \\
Suhu Tanah $\left({ }^{\circ} \mathrm{C}\right)$ & $0,0001 * *$ \\
Kadar Air Tanah $(\%)$ & $0,0020 * *$ \\
\hline
\end{tabular}

Keterangan : $\operatorname{tn}=$ tidak nyata dan $* *=$ sangat nyata. 
kerusakan tersebut mungkin menstimulasi pertumbuhan bibit kopi menjadi lebih baik.

Selain karena kadar air tanah, perkembangan nematoda parasit tumbuhan juga dipengaruhi oleh sumber makanannya yaitu akar. Hal ini tampak dari korelasi positif $(r=0,57)$ antara massa akar dengan kelimpahan nematoda parasit tumbuhan (Tabel 4). Kelimpahan nematoda tinggi pada bibit kopi yang tumbuh baik (biomassa tinggi) yaitu pada tingkat kerapatan naungan 40-50\% (Gambar 1 dan Gambar 3).

Nekrotik akar tidak nyata berkorelasi dengan berat kering akar, tetapi nekrotik akar sangat nyata $(P<0,01)$ berkorelasi negatif dengan berat kering tajuk dan akar+tajuk (Tabel 3). Hal ini menunjukkan bahwa nekrotik akar yang ditimbulkan oleh serangan nematoda tidak dipengaruhi oleh berat kering akar. Nekrotik akar akan turun bila pertumbuhan bibit kopi meningkat. Dalam penelitian ini penggunaan peubah persentase nekrotik akar belum dapat mengindikasikan kerusakan tanaman tersebab nematoda parasit tumbuhan. Hal ini dapat terjadi karena tingkat kerusakan tanaman dipengaruhi oleh faktor tanaman, jenis nematoda dan lingkungan (Desaeger et al., 2004). Oleh karena itu, dalam penelitian selanjutnya perlu digunakan indikator kerusakan tanaman tersebab serangan nematoda lainnya.
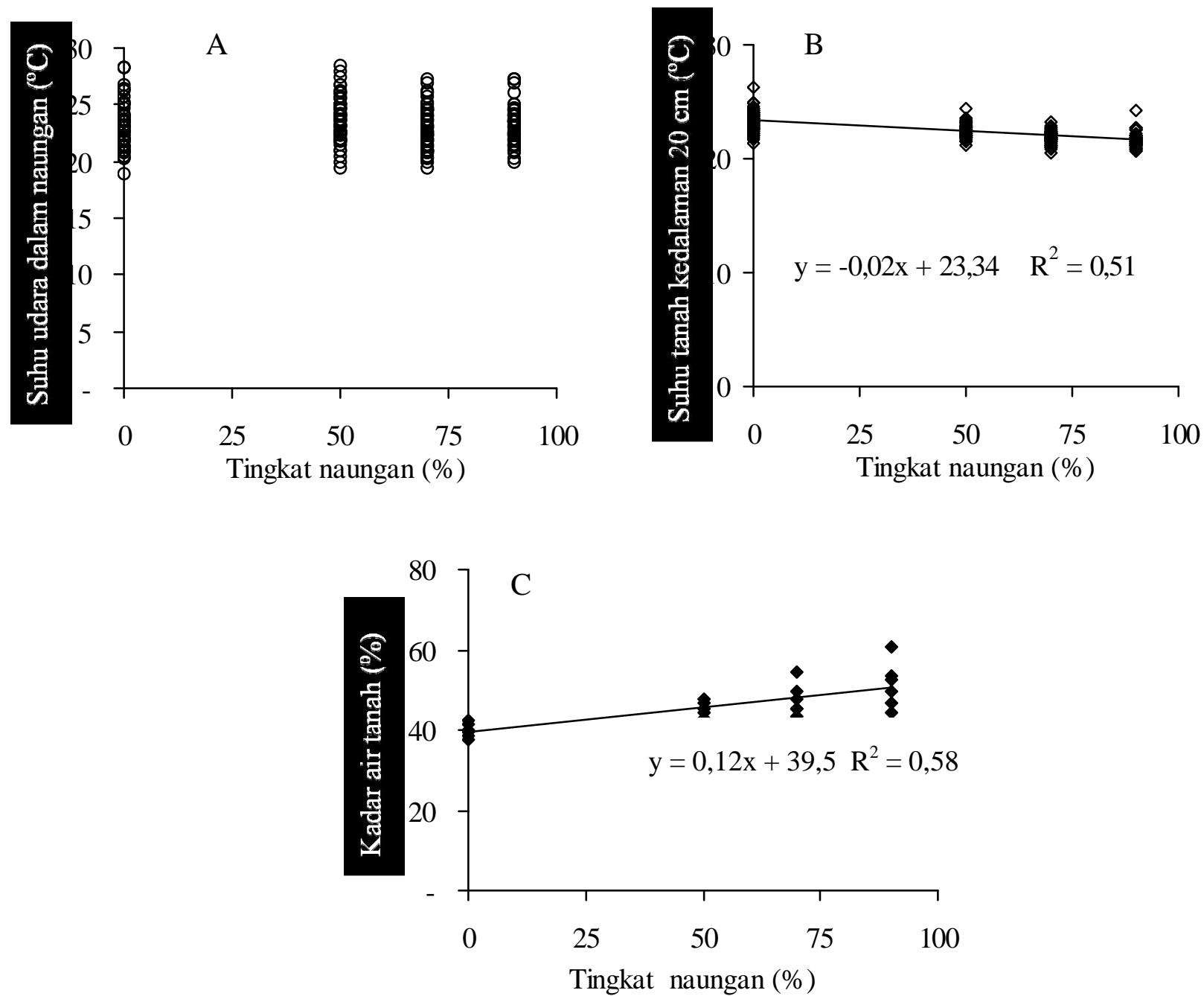

Gambar 2. Hubungan tingkat kerapatan naungan dengan suhu udara di bawah naungan (A), suhu tanah (B), dan kadar air tanah (C) pada kedalaman 0-20 cm pada pembibitan kopi 


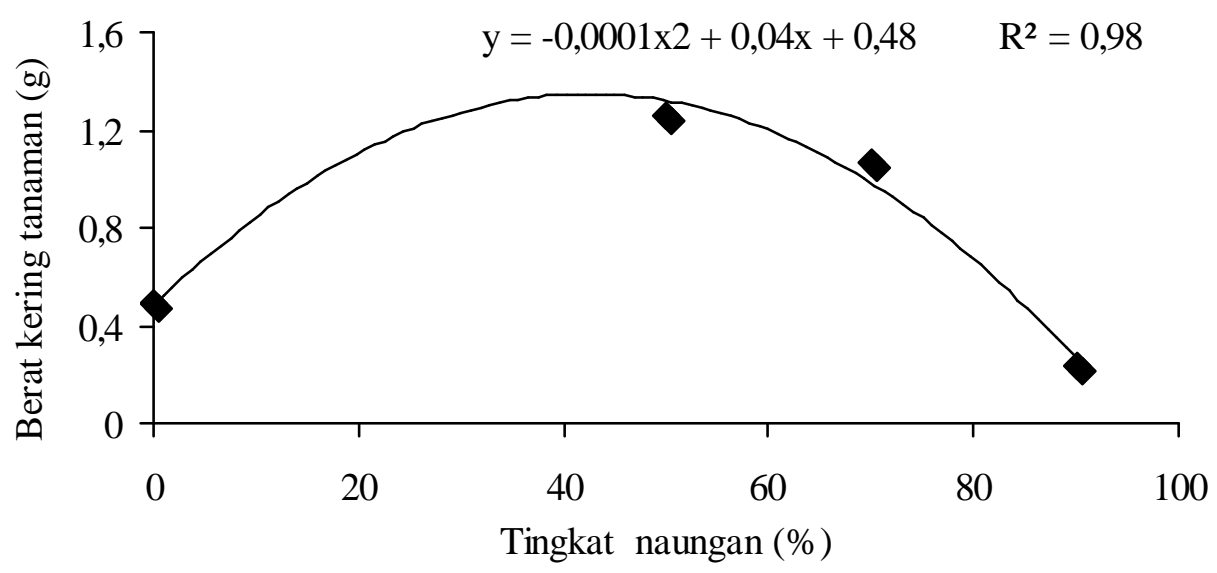

Gambar 3. Hubungan tingkat kerapatan naungan dengan berat kering akar dan tajuk bibit kopi umur 3 bulan setelah tanam

Tabel 3. Koefisien korelasi ( $r$ ) kelimpahan nematoda parasit tumbuhan dalam tanah dan nekrotik akar dengan biomassa tanaman

\begin{tabular}{ccccc}
\hline \multirow{2}{*}{ Peubah } & \multirow{2}{*}{ Nekrotik akar } & \multicolumn{3}{c}{ Berat kering tanaman } \\
\cline { 3 - 5 } & & Akar & Tajuk & (Akar + Tajuk) \\
\hline Kelimpahan nematoda parasit tumbuhan & th & $0,57^{*}$ & $0,61 *$ & $0,64 * *$ \\
Nekrotik akar & & th & $-0,62^{* *}$ & $-0,62^{* *}$ \\
\hline
\end{tabular}

Keterangan: tn $=$ tidak nyata, $*=$ nyata $(P<0,05)$ dan $* *=$ sangat nyata $(P<0,01), \mathrm{n}=16$.

Dari hasil identifikasi diketahui bahwa nematoda parasit tumbuhan yang dominan pada percobaan ini adalah Criconematidae terutama genus Criconemella (78\%), selebihnya Helicotylenchus dan Tylenchida lain $(8 \%)$ serta Dorylaimida (14\%). Criconematidae merupakan nematoda ektoparasit migratory (kembara) yang sebarannya luas dan sering ditemukan berasosiasi dengan tanaman kopi, tetapi patogenisitasnya belum banyak dilaporkan (Campos \& Villain, 2005). Kerusakan akar tanaman oleh nematoda akan rendah bila tanaman tumbuh optimum karena tanaman menjadi lebih tahan, tetapi sebaliknya bila tanaman tercekam (Agrios, 1997). Pertumbuhan bibit kopi dapat tercekam bila kondisi terbuka (naungan 0\%) sehingga tanaman menjadi lebih rentan terhadap serangan hama dan patogen. Oleh karena itu, menurut Schroth et al. (2000) memberi naungan pada tanaman kopi akan dapat meningkatkan ketahanan tanaman terhadap gangguan hama dan penyakit. 


\section{SIMPULAN}

1. Tingkat kerapatan naungan pada bibit kopi berpengaruh nyata terhadap kelimpahan nematoda parasit tumbuhan tetapi tidak berpengaruh terhadap nematoda hidup bebas. Hubungan antara kelimpahan nematoda parasit tumbuhan dengan tingkat kerapatan naungan bersifat polinomial, dengan kelimpahan tertinggi 500 individu per 300 ml tanah pada naungan $40 \%$.

2. Peningkatan kerapatan naungan berpengaruh tidak langsung terhadap peningkatan kelimpahan nematoda melalui peningkatan kadar air tanah.

3. Aplikasi pemupukan N, P dan K pada dosis anjuran untuk bibit kopi meningkatkan kelimpahan nematoda parasit tumbuhan dari 216 menjadi 282 individu per $300 \mathrm{ml}$ tanah.

\section{DAFTAR PUSTAKA}

Afandi. 2004. Benchmark Description: Benchmark and Window Level Information. Progress Report CSM-BGBD Project, Universitas Lampung (unpublished).

Agrios GN. 1997. Plant Pathology, $4^{\text {th }}$ ed. Academic Press. San Diego, London, Boston, New York, Sydney, and Toronto.

Aini FK, Susilo FX, Yanuwiadi B \& Hairiah K. 2006. Meningkatnya potensi sebaran hama rayap Odontotermes spp. setelah alih guna hutan menjadi agroforestri berbasis kopi: apakah perubahan iklim mikro lebih mempengaruhi perubahan populasi daripada ketersediaan makanan? Agrivita (28) 3: 221-227.

Altieri MA \& Nicholls C. 2004. Biodiversity and Pest Management in Agroecosystem $2^{\text {nd }} \mathrm{ed}$. Food Product Press, New York, London and Oxford.

Campos VP \& Villain L. 2005. Nematode Parasite of Coffee and Cocoa. Pp. 529-580 In: Luc M, Sikora RA \& Bridge J, eds. Plant Parasitic Nematodes in Sub-Tropical and Tropical Agriculture. CAB International, Wallingford, UK.
Desaeger J, Rao MR \& Bridge J. 2004. Nematodes and Other Soilborne Pathogen in Agroforestry. Pp. 41-57 In: van Noordwijk M, Cadish G \& Ong CK, eds. Below-Ground Interaction in Tropical Agroecosystem: Concepts and Model with Multiple Plant Components. CAB International, Wallingford, UK.

Gafur A \& Swibawa IG. 2004. Methods in Nematodes and Soil Microbe Research for Belowground Biodiversity Assessment. Pp. 117-123 In: Susilo FX, Gafur A, Utomo M, Evizal R, Murwani S \& Swibawa IG, eds. Conservation and Sustainable Management of BelowGround Biodiversity in Indonesia, Universitas Lampung, Lampung.

Hairiah K, Utami SR, Suprayogo D, Widianto, Sitompul SM, Sunaryo, Mulia R, van Noordwijk M \& Cadisch G. 2000. Agroforestry on Acid Soil in the Humid Tropics: Managing Tree-SoilCrop Interactions. ICRAF, Bogor.

Hulupi R, Soemarno, Mulyadi \& Nasrulah. 2006. Ketahanan beberapa genotipe kopi terhadap nematoda penggali akar Radopholus similis Cobb. Agrosains 19(3): 337-346.

Lavelle P \& Spain AV. 2001. Soil Ecology. Kluwer Academic Publisher. Dordrecht, Boston, London.

Lee DL \& Atkinson HJ. 1997. Physiology of Nematode. Columbia University Press, New York.

Melakeberhan H. 2007. Effect of starter nitrogen on soybean under Heterodera glycine infestation. Plant Soil 301: 111-121.

Najiyati S \& Danarti. 2007. Kopi: Budidaya dan Penanganan Lepas Panen. Penebar Swadaya, Jakarta.

Norton DC. 1978. Ecology of Plant Parasitic Nematodes. John Willey and Sons, New York, Chichester, Brisbane, and Toronto. 
SAS Institute. 1990. SAS Campus Drive, Cary, North Carolina, USA.

Schroth G, Krauss U, Gasparotto L, Aguilar JAD \& Vohland K. 2000. Pest and diseases in agroforestry system of humid tropics. Agroforestry System 50: 199-241.

Smithson PC, McIntyre BD, Gold CS, Ssali H \& Kashaija IN. 2001. Nitrogen and potassium fertilizer vs. nematodes and weevil effects on yield and foliar nutrient status of banana in Uganda. Nutrient Cycling 59: 239-250.
Swibawa IG, Aeny TN, Mashyuda I, Susilo FX \& Hairiah K. 2006. Alih guna lahan hutan menjadi lahan pertanian: Keragaman dan kelimpahan nematoda. Agrivita 28(3): 252266.

Yeates GW. 1996. Diversity of nematode fauna under three vegetation types on pallic soil in Otago, New Zealand. New Zealand Journal of Zoology 23: 401-407. 